\title{
Sistem Pakar Mendiagnosa Penyakit Batu Karang Menggunakan Metode Dempster Shafer
}

\author{
Yolanda Wiguna*, Faisal Taufik**, Asyahri Hadi Nasyuha*** \\ * Sistem Informasi, STMIK Triguna Dharma, Medan \\ ** Sistem Informasi, STMIK Triguna Dharma Medan
}

\begin{tabular}{l}
\hline \hline Article Info \\
\hline Article history: \\
Received Jan $02^{\text {th }}, 2022$ \\
Revised Jan $15^{\text {th }}, 2022$ \\
Accepted Jan $27^{\text {th }}, 2022$
\end{tabular}

\section{Keyword: \\ Batu Karang \\ Dempster Shafer \\ Penyakit \\ Sistem Pakar \\ Web}

\begin{abstract}
Batu karang atau batu saluran kemih merupakan suatu endapan kecil dan keras yang terbentuk di ginjal, saluran kemih dan sering menimbulkan rasa sakit saat buang air kecil, dikarenakan pengetahuan masyarakat yang minim terhadap masalah penyakit batu karang, dan untuk mengetahui keadaan tersebut biasanya masyarakat melakukan pemeriksaan ke Rumah Sakit atau dokter. Namun hal ini tidak semua orang dapat melakukannya, hal ini dapat dikarenakan faktor perekonomian yang kurang mencukupi ataupun jarak yang jauh untuk mendatangi dokter, terdapat pula kelemahan setiap jam kerja praktek dokter yang terbatas. Oleh karena itu diperlukan inovasi dan solusi dalam kondisi tersebut, yaitu dengan memanfaatkan teknologi komputer untuk membangun sistem pakar yang memiliki kemampuan selayaknya seorang pakar dalam melakukan diagnosa. Hasil dari penelitian ini menunjukkan bahwa adanya metode Dempster Shafer yang dihasilkan dari gejala penyakit yang telah di input yaitu berupa jenis penyakit yang telah di proses oleh sistem dan telah disempurnakan ke dalam sebuah aplikasi berbasis web. Dari aplikasi ini diharapkan dapat membantu masyarakat umum dalam pemeriksaan penyakit batu karang.
\end{abstract}

Copyright $($ C) 2022 STMIK Triguna Dharma. All rights reserved.

\section{Corresponding Author:*}

Nama: Yolanda Wiguna

Program Studi: Sistem Informasi

Afiliasi: STMIK Triguna Dharma

Email: yolawiguna@gmail.com

\section{PENDAHULUAN}

Batu karang atau batu saluran kemih merupakan suatu endapan kecil dan keras yang terbentuk diginjal dan sering menimbulkan rasa sakit saat buang air kecil, jika batu tersebut besar maka bisa tersekat di dalam buah pinggang atau saluran kencing dan menyebabkan rasa sakit. Rasa nyeri sering berubah seiring pergerakan batu karang pada saluran urin. Batu karang dapat menimbulkan tanda atau gejala sampai batu tersebut bergerak di dalam ureter pipa yang menghubungkan ginjal dan kandung kemih [1].

Dari beberapa tanda dan gejala yang dirasakan, tidak semua masyarakat mengetahui apakah dirinya mengidap penyakit batu karang atau tidak, dan untuk mengetahui keadaan tersebut biasanya masyarakat melakukan pemeriksaan ke Rumah Sakit atau Dokter. Namun hal ini tidak semua orang dapat melakukannya, hal ini dapat dikarenakan faktor perekonomian yang kurang mencukupi ataupun jarak yang jauh untuk mendatangi Dokter, terdapat pula kelemahan setiap jam kerja praktek Dokter yang terbatas, dan seiring dengan berkembangnya teknologi informasi serta komunikasi yang semakin meningkat, maka kebutuhan akan informasi yang cepat dan akurat menjadi kebutuhan yang utama, terutama dalam perkembangan di dunia medis juga semakin meningkat.

Dengan adanya hal tersebut dapat disimpulkan bahwa perlu dibutuhkan suatu ilmu kecerdasan buatan yaitu sistem pakar dengan metode Dempster Shafer sebagai alternatif informasi dan media komunikasi yang lebih praktis, yang di mana di dalamnya terdapat informasi tentang mendiagnosa penyakit batu karang agar memudahkan pihak Dokter, Asisten Dokter, ataupun masyarakat umum dalam melaksanakan diagnosa sementara, sehingga membantu pihak Dokter untuk mengambil suatu keputusan. 
Sistem pakar pada pertengahan tahun 1960-an mulai di kembangkan oleh Artificial Intelligence Corporation. Sistem pakar yang muncul pertama kali General-purpose Problem Solver (GPS) yang merupakan sebuah predecessor untuk menyusun langkah-langkah yang dibutuhkan untuk mengubah situasi awal menjadi state tujuan yang telah ditentukan sebelumnya dengan menggunakan domain masalah yang kompleks [2].

Sistem pakar atau Expert System biasa disebut juga dengan Knowledge Based System yaitu suatu aplikasi komputer yang ditujukan untuk membantu pengambilan keputusan atau pemecahan persoalan dalam bidang yang spesifik. Sistem ini bekerja dengan menggunakan pengetahuan dan metode analisis yang telah didefinisikan terlebih dahulu oleh pakar yang sesusai dengan bidang keahliannya [3].

Beberapa penelitian dengan metode dempster shafer telah dilakukan, diantaranya sistem pakar mendiagnosis penyakit lumpuh bebek dengan 5 gejala penyakit pada lumpuh bebek maka diambil nilai Dempster Shafer yaitu P3 = 0,341 (34,1\%). Dari gejala yang ada pada lumpuh bebek terkena penyakit dengan keparahan botulism/bakteri [4]. Sistem pakar untuk mendiagnosa penyakit down syndrome menggunakan metode dempster shafer, dengan 4 gejala yang dipilih hasilnya adalah reza aditya mengalami sebuah penyakit down syndrome pada mosaik yaitu dengan nilai keyakinan sebesar 0,633 atau 63,3\% [5].

Analisa gangguan belajar pada anak dengan metode dempster shafer, hasilnya dimana nilai keyakinan paling kuat adalah terhadap gangguan disleksia (a) yaitu sebesar 0.916 yang di dapatkan dari tiga perilaku [6]. Sistem Pakar Mendiagnosa Penyakit Tanaman Solanum Betaccum Menggunakan Metode Dempster Shafer, Hasil perhitungan dengan adanya ke lima gejala yang dipilih oleh konsultasi, maka dapat diperoleh nilai keyakinan paling kuat terhadap P4 yaitu penyakit Virus kuning sebesar 0,5023 atau jika di persentasikan $50 \%$ yaitu cukup pasti [7].

Penrapan metode dempster shafer yang dihasilkan dari gejala penyakit berupa jenis penyakit yang telah di proses oleh sistem dan telah disempurnakan ke dalam sebuah aplikasi berbasis web. Dari aplikasi ini diharapkan dapat membantu masyarakat umum dalam pemeriksaan penyakit batu karang.

\section{METODE PENELITIAN}

\subsection{Proses Pengumpulan Data}

Menjelaskan metodologi penelitian, termasuk desain penelitian, prosedur penelitian (dalam bentuk Penelitian yang baik harus berdasarkan dengan metodologi penelitian yang baik pula. Berikut ini adalah metodologi dalam penelitian ini yaitu:

1. Data Collecting (Teknik Pengumpulan Data )

Ada beberapa teknik yang saya gunakan dalam proses pengumpulan data yaitu:

a. Observasi

Dalam observasi penelitian melakukan pra-riset terlebih dahulu untuk mencari masalah yang terjadi di Klinik Pratama Sehat Husada dalam mengetahui tentang penyakit batu karang berdasarkan gejala yang di alami pasien serta minimnya pengetahuan masyarakat tentang penyakit batu karang. Dari masalah tersebut akan dirumuskan dalam penelitian ini sehingga menemukan apa saja yang perlu dipersiapkan untuk bagaimana menyelesaikan masalah tersebut.

b. Wawancara

Dalam mendapatkan data yang baik, dalam hal ini penelitian melakukan wawancara kepada stakeholder atau pihak-pihak yang terlibat dalam mendukungnya penelitian ini. Dalam hal ini penelitih melakukan wawancara kepada Dokter yang berwenang di klinik tersebut sehingga mendapatkan data penyakit yang lebih valid serta solusi penanganan pertama yang dapat dilakukan untuk menghadapi gejala penyakit yang terjadi.

2. Study of Literature (Studi Kepustakaan)

Dalam penelitian ini, peneliti melakukan studi keputusan yang bersumber dari berbagai referensi diantaranya adalah jurnal nasional dan buku-buku. Adapun referensi tersebut terkait dengan masalah, bidang keilmuan, metode yang digunakan serta aplikasi pendukung lainnya. Terkait bidang keilmuan referensi yang digunakan peneliti yaitu buku terkait bidang sistem pakar dan juga metode Dempster Shafer. 


\subsection{Metode Dempster Shafer}

Metode dempster shafer adalah suatu teori matematika untuk pembuktian berdasarkan belief functions and plausible reasoning (fungsi kepercayaan dan pemikiran yang masuk akal) yang digunakan untuk mengkombinasikan potongan informasi yang terpisah (bukti) untuk mengkalkulasi kemungkinan dari suatu peristiwa. Teori ini dikembangkan oleh P. Dempster dan Glenn Shafer [8].

Pada Dempster Shafer terdapat suatu environment yang merupakan himpunan semesta dari kumpulan hipotesis. Environment berisikan sekumpulan elemen dari kemungkinan jawaban dan hanya terdapat satu elemen yang akan sesuai dengan jawaban yang dibutuhkan [9].

Dempster Shafer adalah suatu teori matematika untuk pembuktian berdasarkan belief functions and plausible reasoning (fungsi kepercayaan dan pemikiran yang masuk akal), yang digunakan untuk mengkombinasikan potongan informasi yang terpisah (bukti) untuk mengkalkulasikan kemungkinan dari suatu peristiwa. Dempster Shafer merupakan metode yang mampu mendiagnosis penyakit berdasarkan fungsi kepercayaan dan pemikiran yang masuk akal sesorang ahli atau pakar [10].

Secara umum teori Dempster Shafer ditulis dalam suatu interval :

1. Belief (Bel) adalah ukuran kekuatan evidence dalam mendukung suatu himpunan proposisi. Jika bernilai

0 (nol) maka mengindikasikan bahwa tidak ada evidence, dan jika bernilai 1 menunjukan adanya kepastian. Dimana nilai bel yaitu (0-0.9).

2. Plausibility/logis (Pls)

Plausibility/logis juga bernilai 0 sampai 1, jika yakin akan - s, maka dapat dikatakan $\operatorname{Bel}(\mathrm{X})=1$ dan $\mathrm{Pl}$ $(\mathrm{Y})=0$, sesuai persamaan $(1)$.

$$
\operatorname{Bel}(\mathrm{X})=\sum_{y=x} \mathrm{~m}(\mathrm{Y})
$$

Sedangkan, Plausibility (Pls) dinotasikan sesuai pada persamaan (2) sebagai berikut.

$\operatorname{Pls}(\mathrm{X})=1-\operatorname{Bel}\left(X^{\prime}\right)=1-\sum_{y=x} \mathrm{~m}\left(\mathrm{X}^{\prime}\right)$

Dimana:

$\operatorname{Bel}(\mathrm{X})=\operatorname{Belief}(\mathrm{X})$

$\operatorname{Pls}(\mathrm{X})=$ Plausibility $(\mathrm{X})$

$\mathrm{m}(\mathrm{X}) \quad=$ mass function dari $(\mathrm{X})$

$\mathrm{m}(\mathrm{Y})=$ mass function $\operatorname{dari}(\mathrm{Y})$

Untuk mengatasi sejumlah evidence tersebut pada teori Dempster-Shafer menggunakan aturan yang lebih dikenal dengan Dempster's Rule of Combination, dinotasikan sesuai pada persamaan (3) sebagai berikut.

$\mathrm{m} 3(\mathrm{Z})=\sum_{X \sim \gamma-Z} \mathrm{~m} 1(\mathrm{X}) \mathrm{m} 2(\mathrm{Y})$

Dimana:

$\mathrm{m} 3(\mathrm{Z}) \quad=$ mass function dari evidence $(\mathrm{Z})$

$\mathrm{m} 1(\mathrm{X}) \quad=$ mass function dari evidence $(\mathrm{X})$

$\mathrm{m} 3(\mathrm{Y})=$ mass function dari evidence $(\mathrm{Y})$

Secara umum formulasi untuk Dempster's Rule of Combination, sesuai dengan persamaan (4) sebagai berikut.

$\mathrm{m} 3(\mathrm{Z})=\sum_{\mathrm{X} N-\mathrm{Z}} \mathrm{m} 1(\mathrm{X}) \mathrm{m} 2(\mathrm{Y})$

$1-\mathrm{K}$

Dimana: $\mathrm{k}=$ Jumlah evidential conflict.

Besarnya jumlah evidential conflict (k) dirumuskan dengan persamaan (5) sebagai berikut.

$K=\sum_{X \cap Y-\theta} \mathrm{m} 1(\mathrm{X}) \mathrm{m} 2(\mathrm{Y})$

Sehingga bila persamaan (5) disubstitusikan ke persamaan (4) akan menjadi:

J-SISKO TECH Vol. 5, No. 1, Januari 2022: 66-75 
$\mathrm{m} 3(\mathrm{z})=\frac{\sum x \cap Y-z \quad m 1(X) \cdot m 2(Y)}{1-\sum x \cap Y-\theta \quad m 1(X) \cdot m 2(Y)}$

Dimana:

$m 3(Z)=$ mass function dari evidence $(\mathrm{Z})$

$m 1(X)=$ mass function dari evidence $(\mathrm{X})$

$m 2(Y)=$ mass function dari evidence $(\mathrm{Y})$

$\mathrm{k} \quad=$ jumlah evidential conflict.

\section{ANALISA DAN HASIL}

\subsection{Penerapan Metode Dempster Shafer}

Algoritma sistem merupakan sebuah tahapan yang dilakukan sebelum melakukan proses diagnosa pada Penyakit Batu Karang dalam memilih back-end programmer dengan menggunkan metode Dempster Shafer.

Hal ini dilakukan untuk membantu atau mempermudah para ahli untuk mendiagnosa suatu penyakit dari beberapa gejala, adapun algoritma sistem diagnosa adalah sebagai berikut:

1. Sumber Pengetahuan meliputi penentuan rule ataupun mesin inferensi, pencarian gejala dan penyakit.

2. Menentukan Basis pengetuan

3. Menentukan nilai Densitas.

4. Menetukan proses perhitungan metode Dempster Shafer.

Untuk nilai densitas dapat dilihat pada tabel 1 di bawah ini beserta penyelesaian proses perhitungan metode Dempster Shafer.

Tabel 1. Nilai Densitas

\begin{tabular}{|c|c|c|c|c|}
\hline No & $\begin{array}{l}\text { Kode } \\
\text { Gejala }\end{array}$ & Nama Gejala & $\begin{array}{l}\text { Nama } \\
\text { Penyakit }\end{array}$ & $\begin{array}{c}\text { Nilai } \\
\text { Densitas }\end{array}$ \\
\hline 1 & G1 & Frekuensi buang air kecil meningkat dan terasa nyeri & P1 (Ureter) & 0,6 \\
\hline 2 & G3 & Urin berwarna gelap atau keruh & $\begin{array}{l}\text { P1 (Ureter) } \\
\text { P2 (Uretra) }\end{array}$ & 0,4 \\
\hline 3 & G4 & $\begin{array}{l}\text { Nyeri hebat dibagian punggung sampai terjadi kolik } \\
\text { (Rasa sakit yang hilang tibul dan menjalar) }\end{array}$ & P1 (Ureter) & 0,7 \\
\hline 4 & G9 & Mual disertai demam & P1 (Ureter) & 0,5 \\
\hline
\end{tabular}

Gejala ke-1 : Frekuensi buang air kecil meningkat dan terasa nyeri (G1).

Apabila diketahui nilai kepercayaan setelah dilakukan observasi "Frekuensi buang air kecil meningkat dan terasa nyeri" sebagai gejala dari penyakit Batu karang Ureter (P1).

$$
\begin{aligned}
\text { Maka }: \mathrm{m} 1\{\text { bel }\} & =0,6 \\
\mathrm{~m} 1\{\theta\} & =1-0,6 \\
& =0,4
\end{aligned}
$$

Gejala ke-2 : Urin berwarna gelap atau keruh (G3).

Apabila diketahui nilai kepercayaan setelah dilakukan observasi berwarna gelap atau keruh" sebagai gejala dari penyakit Batu karang ureter dan uretra $(\mathrm{P} 1, \mathrm{P} 2)$.

$$
\text { Maka } \begin{aligned}
: \mathrm{m} 2\{\text { bel }\} & =0,4 \\
\mathrm{~m} 2\{\theta\} & =1-0,4 \\
& =0,6
\end{aligned}
$$

Aturan kombinasi untuk m3

Tabel 2. Perhitungan Dempster Shafer Terhadap Dua Gejala

\begin{tabular}{lll}
\hline & $\mathrm{m} 2\{\mathrm{p} 1, \mathrm{p} 2\}=0.4$ & $\mathrm{~m} 1\{\theta\}=0.6$ \\
\hline $\mathrm{m} 1\{\mathrm{p} 1\}=0.6$ & $\{\mathrm{p} 1\}=0.24$ & $\{\mathrm{p} 1\}=0.36$ \\
$\mathrm{~m} 1\{\theta\}=0.4$ & $\{\mathrm{p} 1, \mathrm{p} 2\}=0.16$ & $\theta=0.24$ \\
\hline
\end{tabular}

Sehingga dapat dihitung dan hasilnya sesuai dengan tabel 2 di atas. 
$\mathrm{m} 3\{\mathrm{P} 1\}=\frac{0,24+0,36}{1-0}=0,6$

$\mathrm{m} 3\{\mathrm{P} 1, \mathrm{p} 2\}=\frac{0,16}{1-0}=0,16$

$\mathrm{m} 3\{\theta\}=\frac{0,24}{1-0}=0,24$

Gejala ke-3 : Nyeri hebat dibagian punggung sampai terjadi kolik (G4).

Apabila diketahui nilai kepercayaan setelah dilakukan observasi Nyeri hebat dibagian punggung sampai terjadi kolik" sebagai gejala dari penyakit Batu karang Ureter (P1).

Maka $\quad \begin{aligned}: \mathrm{m} 4\{\text { bel }\} & =0,7 \\ \mathrm{~m} 4\{\theta\} & =1-0,7 \\ & =0,3\end{aligned}$

Tabel 3. Perhitungan Dempster Shafer Tiga Gejala

\begin{tabular}{lll}
\hline & $\mathrm{m} 4\{\mathrm{p} 1\}=0,7$ & $\mathrm{~m} 4\{\theta\}=0,3$ \\
$\mathrm{~m} 3\{\mathrm{p} 1\}=0,6$ & $\{\mathrm{p} 1\}=0,42$ & $\{\mathrm{p} 1\}=0,18$ \\
\hline $\mathrm{m} 3\{\mathrm{p} 1, \mathrm{p} 2\}=0,16$ & $\{\mathrm{p} 1\}=0,112$ & $\{\mathrm{p} 1, \mathrm{p} 2\}=0,048$ \\
$\mathrm{~m} 3\{\theta\}=0,24$ & $\{\mathrm{p} 1\}=0,168$ & $\emptyset=0,072$ \\
\hline
\end{tabular}

Sehingga dapat dihitung dan hasilnya sesuai dengan tabel 3 di atas.

$\mathrm{m} 5\{\mathrm{P} 1\}=\frac{0,42+0,112+0,168+0,18}{1-0}=0,88$

$\mathrm{m} 5\{\mathrm{P} 1, \mathrm{P} 2\}=\frac{0,048}{1-0}=0,048$

$\mathrm{m} 5\{\emptyset\}=\frac{0,072}{1-0}=0,072$

Gejala ke-4 : Mual disertai demam (G9).

Apabila diketahui nilai kepercayaan setelah dilakukan observasi " Mual disertai demam" sebagai gejala dari penyakit Batu karang ureter $(\mathrm{P} 1)$

$$
\text { Maka } \begin{aligned}
: \operatorname{m6}\{\text { bel }\} & =0,5 \\
\operatorname{m6}\{\theta\} & =1-0,5 \\
& =0,5
\end{aligned}
$$

Tabel 4. Perhitungan Dempster Shafer Empat Gejala

\begin{tabular}{lll}
\hline & $\mathrm{m} 6\{\mathrm{p} 2\}=0,5$ & $\mathrm{~m} 6\{\theta\}=0,5$ \\
\hline $\mathrm{m} 5\{\mathrm{p} 1\}=0,88$ & $\{\mathrm{p} 1\}=0,44$ & $\{\mathrm{p} 1\}=0,044$ \\
$\mathrm{~m} 5\{\mathrm{p} 1, \mathrm{p} 2\}=0,048$ & $\{\mathrm{p} 1\}=0,024$ & $\{\mathrm{p} 1, \mathrm{p} 2\}=0,024$ \\
$\mathrm{~m} 5\{\theta\}=0,072$ & $\{\mathrm{p} 1\}=0,036$ & $\varnothing=0,036$ \\
\hline
\end{tabular}

Sehingga dapat dihitung dan hasilnya sesuai dengan tabel 4 di atas.

$\mathrm{m} 7\{\mathrm{P} 1\}=\frac{0,44+0,024+0,036+0,44}{1-0}=0,94$

$\mathrm{m} 7\left\{\mathrm{P} 1_{,} \mathrm{P} 2\right\}=\frac{0,024}{1-0}=0,024$

$\mathrm{m} 7\{\emptyset\}=\frac{0,036}{1-0}=0,036$

Dari perhitungan diatas dengan 4 gejala pada penyakit batu karang, maka diambil nilai dempster shafer yaitu $\mathrm{p} 1=0,94$ yang menyatakan bahwa dari gejala yang ada maka pasien tersebut terkena penyakit batu karang jenis ureter.

J-SISKO TECH Vol. 5, No. 1, Januari 2022: 66-75 


\subsection{Implementasi Sistem}

\section{Halaman Utama}

Berikut gambar 1 merupakan tampilan dari halaman utama, fungsi halaman utama adalah sebagai akses masuk ke menu halaman selanjutnya.

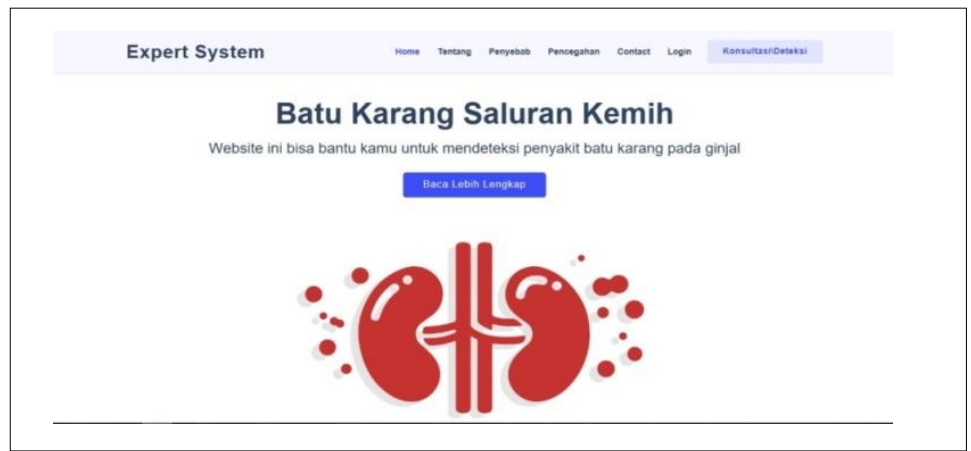

Gambar 1. Tampilan Halaman Utama

2. Halaman Tentang Penyakit

Halaman Tentang Penyakit akan mulcul ketika di klik tentang pada halaman utama, fungsi halaman tentang adalah menampilkan pembahasan terkait penyakit batu karang, tampilan halaman tentang dapat dilihat pada gambar 2 sebagai berikut:

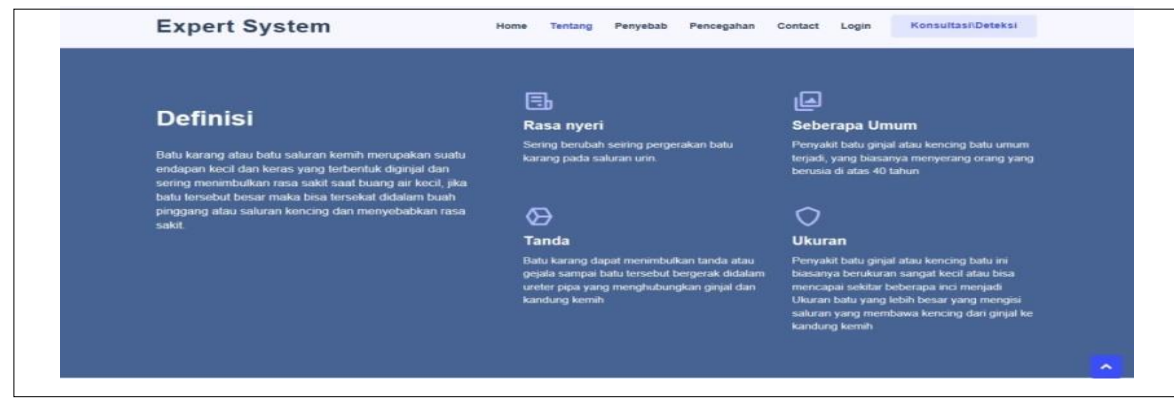

Gambar 2. Tampilan Halaman Tentang Penyakit

3. Halaman Penyebab

Halaman ini berfungsi untuk menampikan penyebab terjadinya penyakit batu karang, tampilan halaman tentang dapat dilihat pada gambar 3 sebagai berikut:

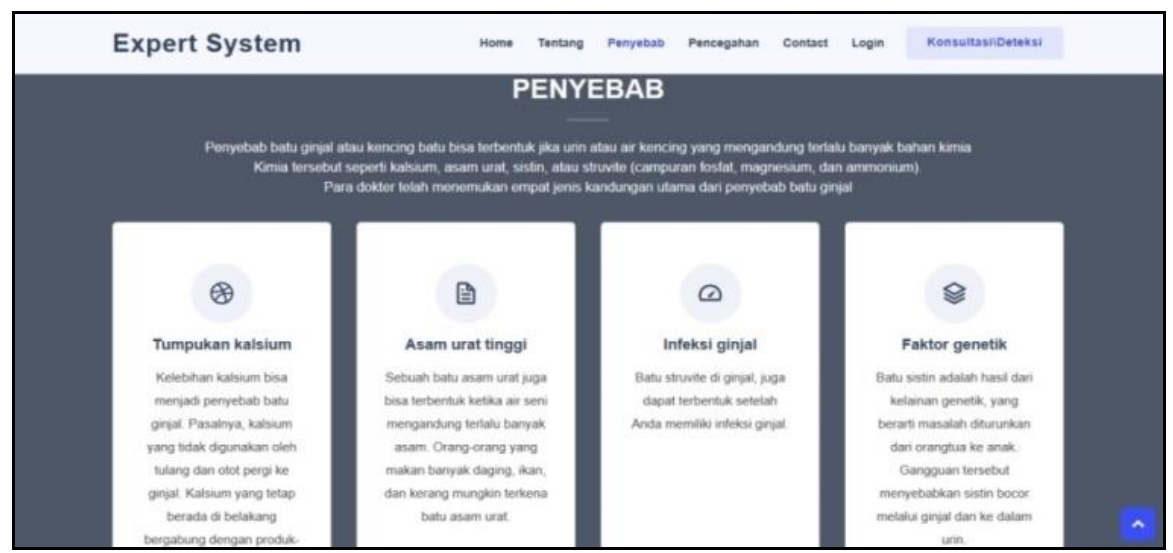

Gambar 3. Tampilan Halaman Tentang Penyebab 
4. Halaman Pencegahan

Halaman Pencegahan akan mulcul ketika di klik pencegahan pada halaman utama, fungsi halaman pencegahan adalah menampilkan pembahasan tentang apa saja penjegahan dari penyakit batu karang, tampilan halaman pencegahan dapat dilihat pada gambar sebagai berikut:

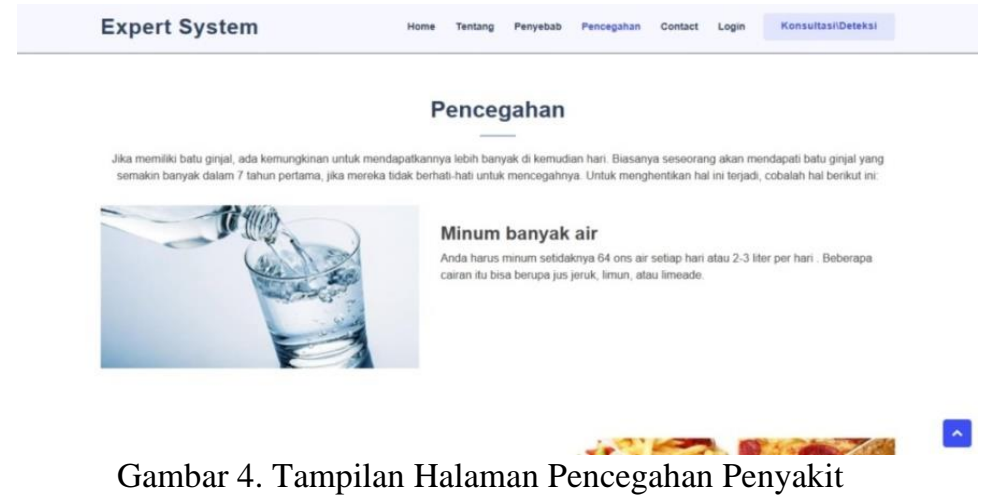

\section{Halaman Gejala}

Halaman gejala memiliki fungsi sebagai edit, hapus dan menambahkan gejala, tampilan halaman gejala dapat dilihat pada gambar 5 sebagai berikut:

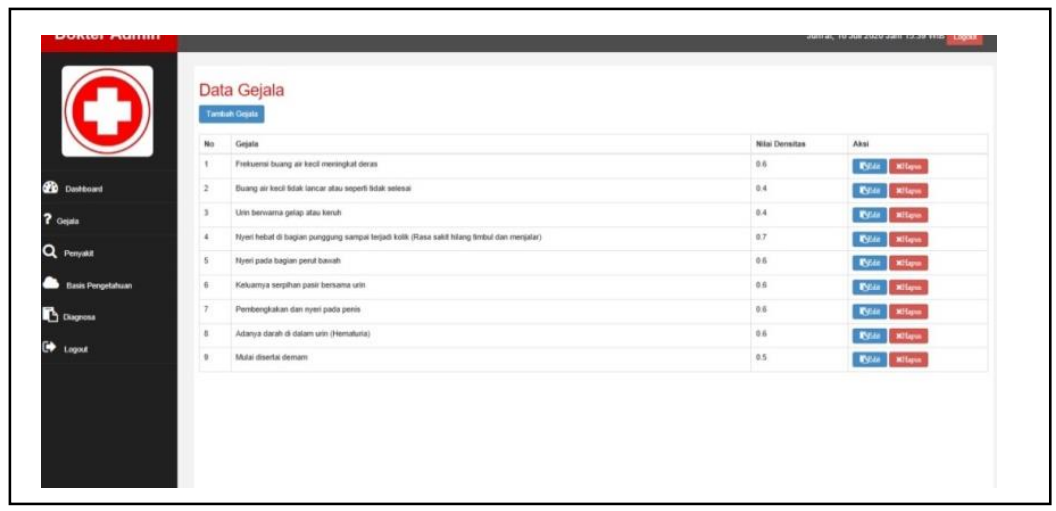

Gambar 5. Tampilan Halaman Gejala

6. Halaman Penyakit

Halaman penyakit akan muncul ketika admin menekan tombol penyakit, halaman ini memiliki fungsi sebagai edit, hapus dan menambahkan nama penyakit baru, tampilan halaman penyakit dapat dilihat pada gambar 6 sebagai berikut:

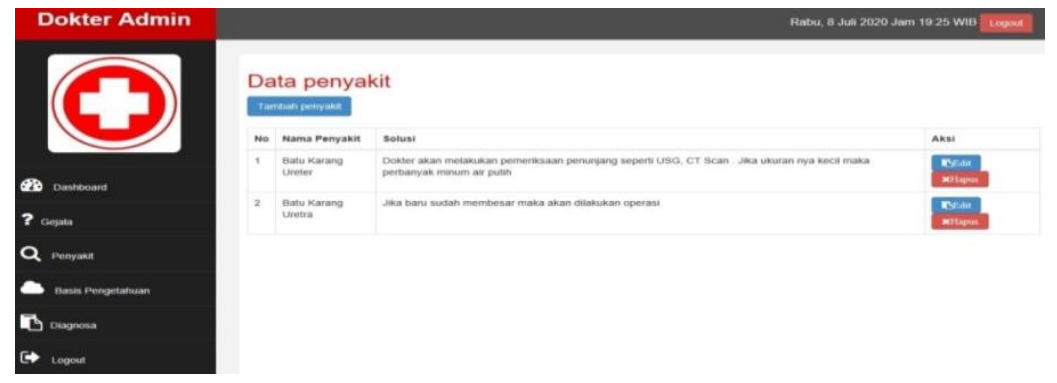

Gambar 6. Tampilan Halaman Penyakit

J-SISKO TECH Vol. 5, No. 1, Januari 2022: 66-75 


\section{Halaman Basis Pengetahuan}

Halaman basis pengetahuan akan muncul ketika admin menekan tombol basis pengetahuan, tampilan halaman basis pengetahuan dapat dilihat pada gambar 7 sebagai berikut:

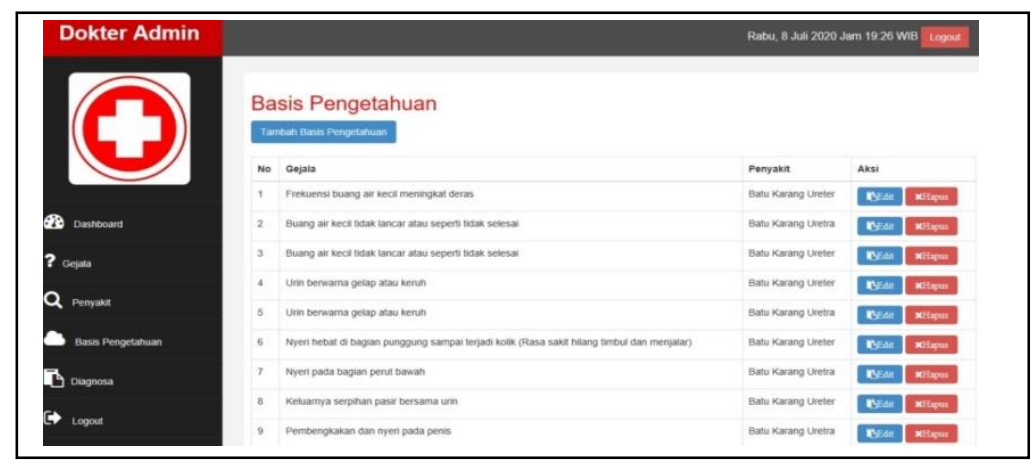

Gambar 7. Tampilan Halaman Basis Pengetahuan

\section{Halaman Diagnosa}

Halaman diagnosa akan muncul ketika admin menekan tombol diagnosa, halaman diagnosa ini akan menampilkan data-data pasien yang sudah melakukan konsultasi, tampilan halaman diagnosa dapat dilihat pada gambar 8 sebagai berikut:

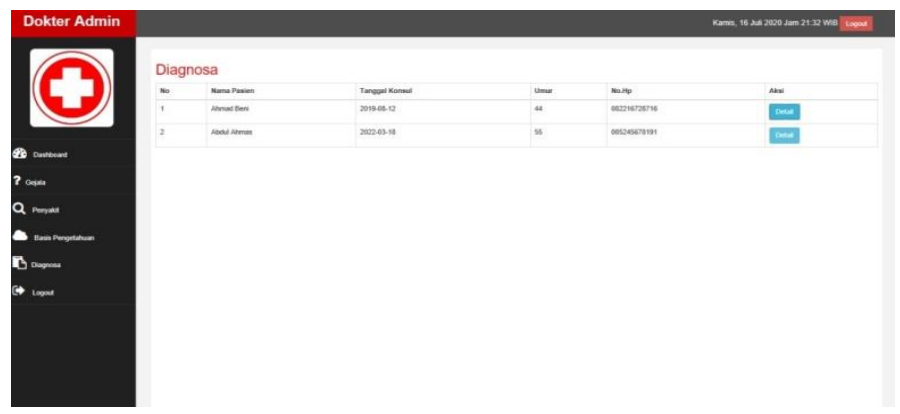

Gambar 8. Tampilan Halaman Diagnosa

9. Halaman Hasil Konsultasi

Halaman hasil konsultasi akan muncul ketika admin menekan tombol submit form, tampilan halaman hasil konsultasi dapat dilihat pada gambar 9 sebagai berikut:

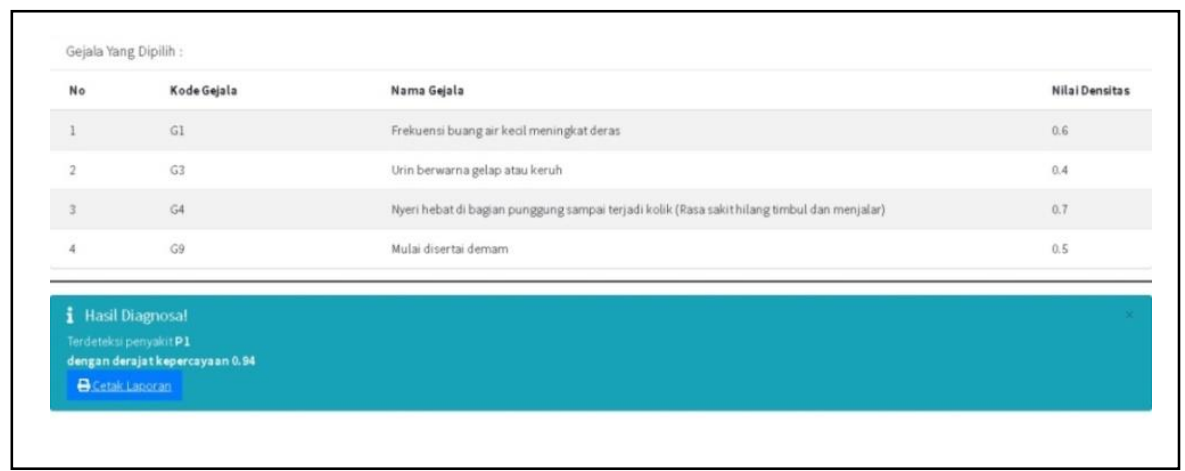

Gambar 9. Tampilan Hasil Konsultasi 
10. Halaman Laporan

Halaman laporan akan muncul ketika sudah mengisi data di form konsultasi dan mengklik tombol submit form untuk menampilkan hasil laporan, fungsi halaman laporan ini adalah untuk menampilkan hasil dari diagnsa penyakit, tampilan hlaman laporan dapat dilihat pada gambar 10 sebagai berikut:

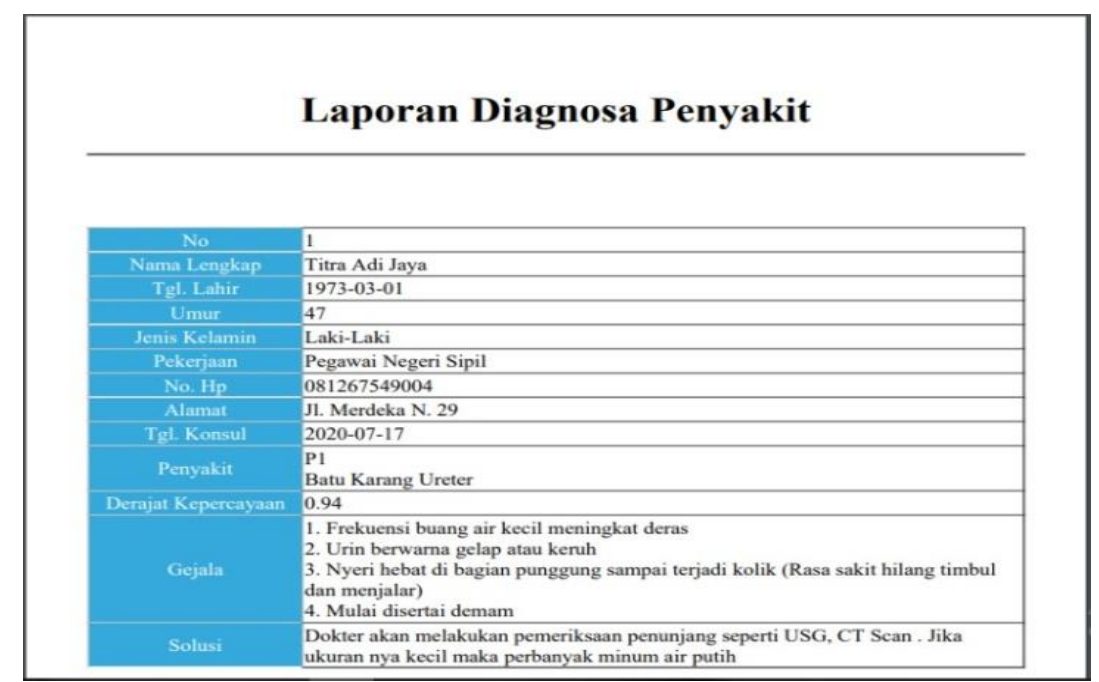

Gambar 10. Tampilan Halaman Laporan

\section{KESIMPULAN}

Berdasarkan analisa pada permasalahan yang terjadi dalam kasus yang diangkat tentang Implementasi Sistem Pakar Untuk Mendiagnosa Penyakit Batu Karang Menggunakan Metode Dempster Shafer, maka ditarik beberapa kesimpulan sebagai berikut :

1. Mendiagnosa penyakit Batu Karang dengan mengimplementasikan Sistem Pakar menggunakan Metode Dempster Shafer yang berwal dari menentukan nilai densitas dan plausibility, selanjutnya melakukan proses kombinasi Dempster Shafer.

2. Untuk merancang sistem pakar dengan menggunakan metode Dempster Shafer untuk mendiagnosa penyakit batu karang dapat dirancang dengan baik menggunakan UML dan Flowchart untuk menggambarkan sistem yang akan dibangun. UML terdiri dari Use Case Diagram, Activity Diagram, dan Class Diagram

3. Pengujian dan Pengimplementasian sistem yang dirancang dilakukan dengan cara penerapan sistem untuk Masyarakat Umum dan pihak Dokter. Setelah itu melakukan evaluasi terhadap sistem yang telah dicoba, sehingga mengetahui apakah sistem yang dibangun telah sesuai atau belum.

\section{UCAPAN TERIMA KASIH}

Terimakasih diucapkan kepada Bapak Faisal Taufik dan Bapak Asyahri Hadi Nasyuha yang telah mendukung dalam penyelesaian penelitian ini. Kiranya bisa memberi manfaat bagi pembaca dan dapat meningkatkan kualitas penelitian selanjutnya.

\section{REFERENSI}

[1] I. Russari, “SISTEM PAKAR DIAGNOSA PENYAKIT BATU GINJAL,” pp. 18-22, 2016.

[2] A. S. Sembiring, "TANAMAN PADI Diterbitkan Oleh : STMIK Budi Darma Medan Diterbitkan Oleh : STMIK Budi Darma Medan,” vol. III, pp. 6-11, 2013.

[3] B. H. Hayadi, Sistem Pakar. 2015.

[4] K. R. A. B. Sembiring, H. Hafizah, and R. Gunawan, "Sistem Pakar Mendiagnosis Penyakit Lumpuh Bebek Menggunakan Metode Dempster Shafer," J. CyberTech, vol. 1, no. 3, pp. 165-174, 2021. 
[5] S. A. Simamora, K. Erwansyah and U. F. S. S. Pane," Sistem Pakar Untuk Mendiagnosa Penyakit Down Syndrome Menggunakan Metode Dempster Shafer," J. CyberTech, vol. 1, no. 2, pp. 155-164, 2021.

[6] A. Tanaka, Y. Hendro, and R. Amanda, "Website Analisa Gangguan Belajar pada Anak dengan Metode Dempster Shafer," J. SAINTIKOM (Jurnal Sains Manaj. Inform. dan Komputer), vol. 17, no. 2, p. 218, 2018, doi: 10.53513/jis.v17i2.48.

[7] D. S. Lumbanbatu, B. Anwar, and M. Dahria, "Sistem Pakar Mendiagnosa Penyakit Tanaman Solanum Betaccum Menggunakan Metode Dempster Shafer," vol. 1, pp. 1-9, 2022.

[8] Z. Azmi and V. Yasin, Pengantar sistem pakar dan metode. 2017.

[9] E. R. Ritonga and M. D. Irawan, "SISTEM PAKAR DIAGNOSA PENYAKIT PARU-PARU," vol. 2, no. 1, pp. 39-47, 2017.

[10] E. Sagala, J. Hutagalung, S. Kusnasari, Z. Lubis, "Penerapan Sistem Pakar Dalam Mendiagnosis penyakit Tanaman Carica Papaya di UPTD . Perlindungan Tanaman Pangan dan H. Menggunakan D. Shafer," vol. 1, no. 1, pp. 95$103,2021$.

\section{BIOGRAFI PENULIS}

\begin{tabular}{|l|l|}
\hline Yolanda Wiguna & \\
\hline & $\begin{array}{l}\text { Nama : Faisal Taufik, S.Kom.,M.Kom } \\
\text { NIDN : 0104038603 } \\
\text { Program Studi : Sistem Informasi } \\
\text { Deskripsi : Dosen Tetap STMIK Triguna Dharma yang aktif } \\
\text { mengajar dan fokus pada bidang keilmuan } \\
\text { Prestasi : - }\end{array}$ \\
\hline & $\begin{array}{l}\text { Nama : Dr. Asyahri Hadi Nasyuha } \\
\text { NIDN : 0129048601 } \\
\text { Program Studi : Sistem Informasi } \\
\text { Deskripsi : Dosen Tetap STMIK Triguna Dharma yang aktif } \\
\text { mengajar dan fokus pada bidang keilmuan Komputer serta aktif } \\
\text { dalam organisasi Cyber Programing Club. Telah menulis 3 (Tiga) } \\
\text { buku dibidang Ilmu komputer. Memiliki sebanyak 2 (Dua) Hak } \\
\text { Kekayaan Intelektual (HKI). Menjabat sebagai Ketua Lembaga } \\
\text { Penjaminan Mutu } \\
\text { Prestasi : Finalis Lomba Aplikasi Mobile Kihajar 2018 BPMPK } \\
\text { Kemendikbud Kategori Umum V-Lab, Hibah PDP 2020, Lulusan } \\
\text { Terbaik S3 Fakultas Teknik Program Studi Pendidikan Teknologi } \\
\text { Kejuruan, Universitas Negeri Padang. }\end{array}$ \\
\hline
\end{tabular}

